\title{
CLIMATE CHANGE: PERCEPTION AND ADAPTATION RESPONSES OF POULTRY SMALLHOLDER FARMERS IN AMATHOLE DISTRICT MUNICIPALITY, EASTERN CAPE PROVINCE OF SOUTH AFRICA
}

\author{
Popoola, O. O. ${ }^{1}$, Monde, N. ${ }^{2}$ and Yusuf, S. F. G. ${ }^{3}$ \\ Correspondence author: O. O. Popoola. Email: sopeinoluwabunmi@gmail.com
}

\begin{abstract}
Characterised by high industrialisation, consumption, and trade, poultry production has become a predominant component of the agricultural industry. Climate change, however, is posing a critical challenge to its sustainability and rural sustenance. It has therefore become exigent to assess these impacts and available adaptation efforts put in place to assuage these risks. A multistage sampling procedure was used to select 101 smallholder poultry farmers in 18 villages across the Amathole District Municipality in the Eastern Cape Province of South Africa. An assessment of climate change and perceived impact on production, adaptation responses, and effectiveness of the responses were carried out using simple descriptive and inferential statistical tools. The results show that reduction in quantity of egg production, egg quality and sizes, loss of weight affecting meat production, increase in cost of feeding, disease spread, and mortality rate of birds are the most perceived impacts of climate change. The adaptation responses of the poultry farmers in the area are extremely limited, with only three adaptation measures available. These measures include rearing different varieties of birds, destocking, and dependence on social welfare, which was found to be taken up by more than half of the poultry farmers. However, none of these adaption measures were perceived as effective, suggesting poor adaptation to climate change in the study area.
\end{abstract}

Keywords: poultry production, climate change, perceived impacts, adaptation measures, perceived effectiveness

\section{INTRODUCTION}

Climate dynamics are variabilities and changes of the climatic system which takes into account changes in temperature, rainfall, wind strength and direction, amongst other climate variables (Agnew \& Goodess, 2009). Climate change is a global threat (Okonya, Syndikus \& Kroschel, 2013). It is inevitable that climate variabilities will adversely impact agricultural production, exacerbate agricultural productivity decline, affect food insecurity, and challenge sustainable development, particularly rural sustenance (Coster \& Adeoti, 2015; Eitzinger et al, 2010; Juana, Kahaka \& Okurut, 2013).

The poultry sector is critical to the agricultural industry. It is characterised by higher industrialisation, consumption, and trade than other major sectors in the industry (Mengesha, 2011; Sebho, 2016). Poultry production is a central component to virtually all rural, semi-urban

\footnotetext{
${ }^{1}$ Research Fellow, Department of Agricultural Economics and Extension, University of Fort Hare, Alice, South Africa, Email: sopeinoluwabunmi@gmail.com or 201514620@ufh.ac.za, ORCiD 0000-0002-8514-5713

${ }^{2}$ Dean, Faculty of Science and Agriculture, University of Fort Hare, Alice, South Africa, Email: nmonde@ufh.ac.za, ORCiD 0000-0002-6854-2928

${ }^{3}$ Senior Lecturer, Department of Agricultural Economics and Extension, University of Fort Hare, Alice, South Africa, Email: fyusuf@ufh.ac.za or gbolahan4la@yahoo.com, ORCiD 0000-0002-4156-1221
} 
and urban households (Permin, Pedersen \& Riise, 2001), and is of economic, dietary and sociocultural importance, particularly to poor rural communities (Adesiji, Baba \& Tyabo, 2013). It is also a significant contributor of meat, egg and other raw materials to industries (Ravichandran \& Mohamed, 2015). According to Besbes et al (2007), there are two basic poultry production systems. Firstly, the commercial system, which is highly integrated and industrialised and involves the rearing of hybrids, and secondly, the village/backyard system, which involves raising indigenous breeds.

Temperature and relative humidity, which are critical elements of the climatic system, are known to affect performance and productivity efficiencies of poultry birds (Chah et al, 2013; Elijah \& Adedapo, 2006). According to Moorhead (2009), it is certain that global temperatures are on the rise and will continue to rise in the coming years, challenging several agricultural systems, including poultry. Amongst other factors, diseases, pests and parasites, as well as stress and nutrition affect the welfare of poultry birds (Lay et al, 2011), and these are factors that could potentially be conditioned by climate change with severe impact on poultry productivity and profitability. Adejoro (2017) asserts that any factor affecting the poultry industry negatively is considered as severe as it could have profound economic impacts with colossal effects on livelihood sustainability.

It is therefore of high priority to assess the impacts of climate change induced conditions on the poultry sector and adaptation efforts adopted to assuage such impacts. As such, an enhanced understanding of farmers' adaptation capacities could aid in prioritising appropriate adaptation response policies and measures (Kitinya et al, 2012). According to Kassie et al (2013), assessing current available adaptation measures practiced by farming households to combat climate change risks is a vital step in further improving and recommending appropriate adaptation techniques. This is particularly important for the rural resource poor communities where climate change is fast shoving the population beyond their response capacity (Pettengell, 2010). It is against this background that this study aimed to assess the perception of poultry smallholder farmers to climate change, climate change induced risks, the level of severity in the area, perceived impacts of climate change on production, adaptation responses, and perceived effectiveness of the response measures.

\section{METHODOLOGY}

A cross-sectional household survey using a multiple stage sampling procedure (purposive, simple random and snowball sampling) was carried out in Mbashe Local Municipality in the Amathole District of the Eastern Cape Province. This area was purposively selected due to its low-density and extremely rural settlements. A total of 101 smallholder poultry farmers rearing either or both indigenous and hybrid birds were interviewed from 18 villages. The villages were selected from Willowvale, Elliotdale and Idutywa in Mbahashe Local Municipality. Willowvale: Ngxakaxa Sheshegu and Ngxakaxa Phesheya kwe dip (Ward 2); Gwadana Ngaphantsi and Gwadana Phezulu (Ward 3). Elliotdale: Keti Cimakala and Keti Lalini (Ward 31), Nqadu Phezulu and Nqadu Kumaya (Ward 11); Ematolweni and Ntlabane (Ward 25); Nxanxashe and Kwesika Gosani (Ward 30); Khasa and Fameli (Ward 13). Idutywa: Mbanyana and Ntlanyane Kulombombo (Ward 16); Ntlonyane Kulophungla and Ezithenjini (Ward 26). Simple descriptive statistical tools were used to describe respondents' demographic profiles and represent their perceptions towards temperature and rainfall changes. Using mean score values on a Likert-type scale (Farauta et al, 2011), the perceived severity of climate change induced risks were analysed and described. Individual and overall mean scores were computed 
from a three point Likert-type scale of 'Very Severe' $=3$, 'Severe' $=2$, and 'Not severe' $=1$. Risks with a mean score greater or equal to $(\geq) 2.0$ were considered as profound in the area. The extent of perceived climate change impacts on poultry production was also analysed and described using mean score values on a five-point Likert scale of 'To a very great extent' $=5$, 'To a great extent' $=4$, 'To some extent' $=3$, 'To a little extent' $=2$, and 'To no extent' $=1$. Perceived impacts with a mean score greater or equal to $(\geq) 3.0$ were also considered as profound impacts on poultry production in the area. Assessment of the poultry farmers' perceptions of the effectiveness of their adaptation responses was also measured on a threepoint Likert scale of 'Very Effective' = 3, 'Effective' = 2, and 'Not Effective' = 1. Adaptation response measures with a mean score greater or equal to $(\geq) 2.0$ were considered as effective measures. Cluster analysis was conducted to generate clusters based on the similarity of responses of respondents to all items provided in the perception of respondents to the impacts of climate change on their production activities. This analysis was carried out using the statistical programme, STATA/SE, version 15.

\section{RESULTS}

Respondents' mean age was $55.51(\mathrm{SD}=13.51)$ years, while the majority $(54.6 \%)$ had either primary school or no formal education.

\subsection{Perceived impacts of climate change on agricultural productivity}

Farmers perceived a reduced quantity of egg production $(\overline{\mathrm{x}}=3.41)$, egg quality and sizes $(\overline{\mathrm{x}}=$ $3.20)$, loss of weight affecting meat production $(\overline{\mathrm{x}}=3.71)$, and an increased mortality rate of birds $(\overline{\mathrm{x}}=2.89)$ as some of the climate change impacts affecting poultry production in the region (Table 1$)$.

\subsection{Adaptation responses and perceived effectiveness of adopted response measures}

Adaptation responses were limited to rearing different varieties of birds $(51 \%, \overline{\mathrm{x}}=1.07)$, destocking $(73 \%, \bar{x}=1.49)$, and dependence on social welfare $(86 \%, \bar{x}=1.97)$. None of these were perceived as effective response measures (Table 2).

Table 1: Perceptions of the impacts of climate change on poultry production $(n=101)$

\begin{tabular}{|l|c|c|c|c|c|c|c|}
\hline $\begin{array}{l}\text { Perception of } \\
\text { climate change } \\
\text { impacts on } \\
\text { livestock } \\
\text { production }\end{array}$ & $\begin{array}{c}\text { Poultry } \\
\text { farmers } \\
(\%)\end{array}$ & $\begin{array}{c}\text { To no } \\
\text { extent } \\
(\%)\end{array}$ & $\begin{array}{c}\text { To a } \\
\text { little } \\
\text { extent } \\
(\%)\end{array}$ & $\begin{array}{c}\text { To } \\
\text { some } \\
\text { extent } \\
(\%)\end{array}$ & $\begin{array}{c}\text { To a } \\
\text { great } \\
\text { extent } \\
(\%)\end{array}$ & $\begin{array}{c}\text { To a very } \\
\text { great } \\
\text { extent } \\
(\%)\end{array}$ & $\begin{array}{c}\text { Mean } \\
\text { score } \\
\bar{x}\end{array}$ \\
\hline $\begin{array}{l}\text { Increased spread of } \\
\text { poultry diseases }\end{array}$ & 100 & 0 & 6 & 22 & 22 & 50 & $4.16^{*}$ \\
\hline $\begin{array}{l}\text { Reduced quantity } \\
\text { of egg production }\end{array}$ & 100 & 4 & 9 & 43 & 30 & 14 & $3.41^{*}$ \\
\hline $\begin{array}{l}\text { Reduction in } \\
\text { quality and size of } \\
\text { eggs }\end{array}$ & 100 & 1 & 23 & 45 & 17 & 14 & $3.20^{*}$ \\
\hline
\end{tabular}


S. Afr. J. Agric. Ext.

Vol. 47 No. 3, 2019: 108 - 119

http://dx.doi.org/10.17159/2413-3221/2019/v47n3a519
Popoola, Monde \&

Yusuf

(License: CC BY 4.0)

\begin{tabular}{|l|c|c|c|c|c|c|c|}
\hline $\begin{array}{l}\text { Loss of weight } \\
\text { affecting meat } \\
\text { production }\end{array}$ & 100 & 2 & 10 & 24 & 44 & 20 & $3.71^{*}$ \\
\hline $\begin{array}{l}\text { Increase in cost of } \\
\text { feeding }\end{array}$ & 100 & 1 & 5 & 18 & 22 & 54 & $4.27^{*}$ \\
\hline $\begin{array}{l}\text { Increase in water } \\
\text { intake }\end{array}$ & 100 & 3 & 4 & 20 & 36 & 37 & $4.04^{*}$ \\
\hline $\begin{array}{l}\text { Increased cost of } \\
\text { veterinary services }\end{array}$ & 100 & 50 & 27 & 11 & 2 & 10 & 1.95 \\
\hline $\begin{array}{l}\text { Increase cost of } \\
\text { overall } \\
\text { maintenance }\end{array}$ & 100 & 14 & 20 & 29 & 22 & 15 & $3.08^{*}$ \\
\hline $\begin{array}{l}\text { Increased mortality } \\
\text { rate of birds }\end{array}$ & 100 & 7 & 31 & 37 & 16 & 9 & $2.89^{*}$ \\
\hline
\end{tabular}

Note: $*$ = Significant impact if mean score is $\geq 2$

Source: Field survey, 2016

Table 2: Adaptation responses and their perceived effectiveness $(n=101)$

\begin{tabular}{|l|c|c|c|c|c|c|}
\hline $\begin{array}{l}\text { Self-adopted adaptation } \\
\text { responses }\end{array}$ & $\begin{array}{c}\text { Poultry } \\
\text { farmers } \\
(\%)\end{array}$ & $\begin{array}{c}\text { No } \\
(\%)\end{array}$ & \multicolumn{3}{|c|}{$\begin{array}{c}\text { Yes } \\
(\%)\end{array}$} & $\begin{array}{c}\text { Mean } \\
\text { score }\end{array}$ \\
\hline & & & $\begin{array}{c}\text { Not } \\
\text { effective }\end{array}$ & Effective & $\begin{array}{c}\text { Very } \\
\text { effective }\end{array}$ & $\bar{x}$ \\
\hline $\begin{array}{l}\text { Using improved poultry } \\
\text { breeds }\end{array}$ & 100 & 67 & 3 & 22 & 8 & 0.70 \\
\hline $\begin{array}{l}\text { Rearing different varieties } \\
\text { of birds }\end{array}$ & 100 & 49 & 6 & 28 & 17 & 1.07 \\
\hline $\begin{array}{l}\text { Construction of new } \\
\text { buildings with better } \\
\text { natural ventilation system }\end{array}$ & 100 & 75 & 0 & 17 & 8 & 0.57 \\
\hline $\begin{array}{l}\text { Planting fast growing trees } \\
\text { to provide shade for } \\
\text { buildings }\end{array}$ & 100 & 99 & 1 & 0 & 0 & 0.01 \\
\hline $\begin{array}{l}\text { Installing cooling } \\
\text { equipment }\end{array}$ & 100 & 99 & 0 & 0 & 1 & 0.03 \\
\hline Using dose treatments & 100 & 58 & 1 & 33 & 8 & 0.90 \\
\hline Vaccination of birds & 100 & 70 & 0 & 24 & 6 & 0.65 \\
\hline $\begin{array}{l}\text { Increased use of veterinary } \\
\text { services }\end{array}$ & 100 & 97 & 0 & 0 & 3 & 0.10 \\
\hline $\begin{array}{l}\text { Increased quantity of } \\
\text { supplementary feeds }\end{array}$ & 100 & 55 & 1 & 26 & 18 & 1.03 \\
\hline $\begin{array}{l}\text { Diversifying sources of } \\
\text { income }\end{array}$ & 100 & 79 & 6 & 10 & 4 & 0.38 \\
\hline Destocking & 100 & 27 & 16 & 37 & 20 & 1.49 \\
\hline $\begin{array}{l}\text { Switching to another agro } \\
\text { enterprise }\end{array}$ & 100 & 93 & 2 & 5 & 0 & 0.19 \\
\hline
\end{tabular}




\begin{tabular}{|l|c|c|c|c|c|c|}
\hline $\begin{array}{l}\text { Dependent on social } \\
\text { welfare }\end{array}$ & 100 & 14 & 16 & 27 & 43 & 1.97 \\
\hline Use of insurance & 100 & 100 & 0 & 0 & 0 & 0 \\
\hline Selling assets & 100 & 97 & 2 & 1 & 0 & 0.03 \\
\hline
\end{tabular}

Note: $*$ Significant perceived effectiveness if mean score is $\geq 2$

Source: Field survey, 2016

\subsection{Cluster analysis}

A ward's hierarchical cluster analysis was carried out. The simulation process of the cluster analysis allocated the respondents to four clusters and this allocation process led to the frequency of respondent occurrence in each cluster (Table 3). Following Köbrich, Rehman and Khan's (2003) interpretation of the Dendogram, an elbow test verified the ideal number of clusters for the successive clustering method to be $n=4$ (Figure 1), which was consistent with the interpretation of the Dendogram (Burns \& Burns, 2008). G1-G10 in the Dendogram represents the boundary point for each of the clusters generated using each item on the Likert scale for the perceptions of the impacts of climate change on poultry production. The Dendogram was generated by the items fed into the cluster analysis model.

Table 3: Frequencies and percentages of respondents in the four clusters

\begin{tabular}{|c|c|c|}
\hline Clusters & Frequency & Percentage \\
\hline 1 & 12 & 11.88 \\
\hline 2 & 37 & 36.64 \\
\hline 3 & 30 & 29.70 \\
\hline 4 & 22 & 21.78 \\
\hline
\end{tabular}

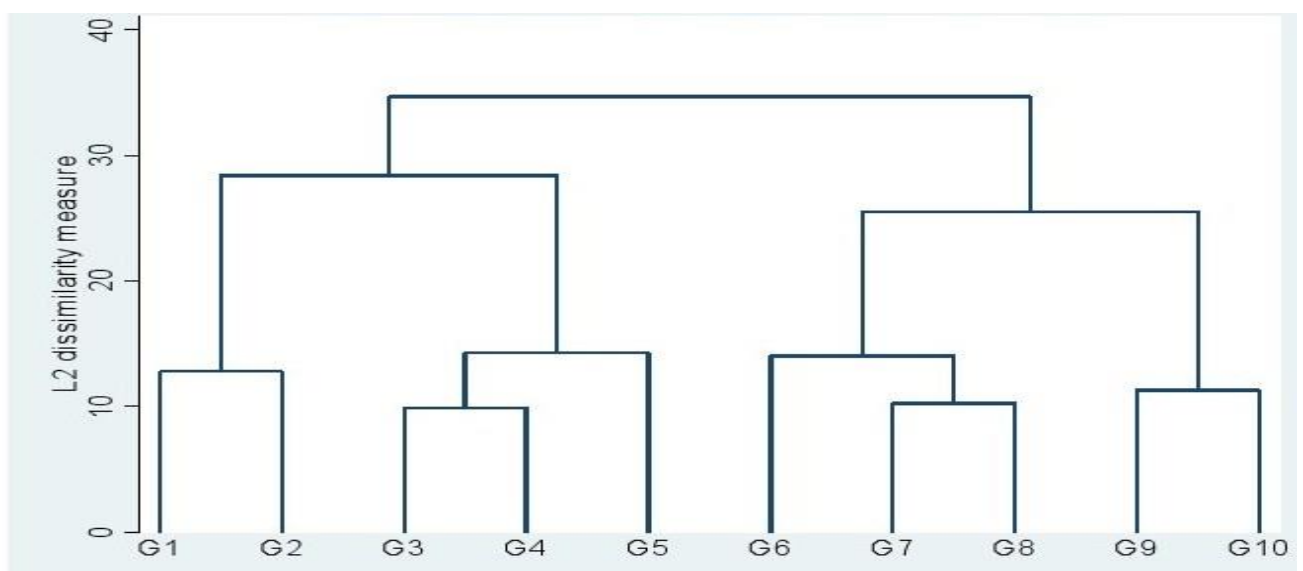

Figure 1: Dendogram for perceived impacts of climate change on poultry production

Further analysis was conducted in generating mean scores for all items in the four clusters (Table 4).

Cluster 1 - Perceived increase in the cost of veterinary services had the highest mean score $(\overline{\mathrm{x}}$ $=4.75$ ) which was found to be significantly higher than the mean scores in other clusters. Only about $11 \%$ of the respondents were grouped in this cluster showing that very few poultry farmers utilised veterinary services in the area. This is also evident in Table 1 where veterinary cost services had no effect on the majority of the farmers as they did not utilise these services. 
S. Afr. J. Agric. Ext.

Vol. 47 No. 3, 2019: $108-119$

http://dx.doi.org/10.17159/2413-3221/2019/v47n3a519
Popoola, Monde \&

Yusuf

(License: CC BY 4.0)

This group of farmers also perceived the high cost of health maintenance as a severe impact of climate change condition.

Cluster 2 - Perception of increased cost of feeding had the highest mean score $(\bar{x}=4.84)$. This mean score was also higher than all other mean scores for cost of feeding in other clusters indicating that it was the most severe impact for poultry farmers in this cluster.

Cluster 3 - Increased incidences of poultry diseases had the highest mean score $(\overline{\mathrm{x}}=4.74)$ which was found to be significantly higher than results obtained from the first, second and fourth clusters. This indicates that respondents in this cluster are faced with more problems of poultry disease occurrence than respondents in other clusters.

Cluster 4 - Perception of increased cost of feeding also had the highest mean score $(\overline{\mathrm{x}}=3.86)$ in this cluster. The mean score was however found to be lower than what was obtained in the second cluster indicating that this impact was not perceived as severe by respondents in cluster four.

Table 4: Generated mean scores for all items in the four clusters

\begin{tabular}{|c|c|c|c|c|c|c|c|c|c|c|}
\hline Clusters & 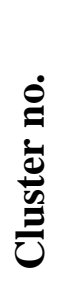 & 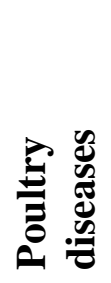 & 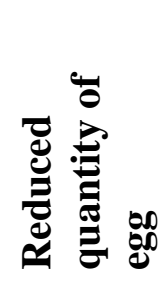 & 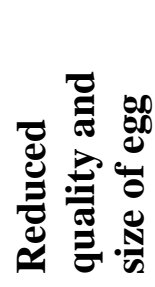 & 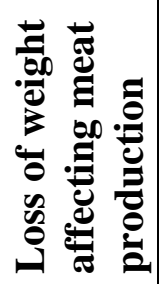 & 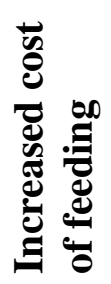 & 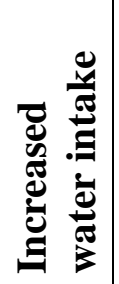 & 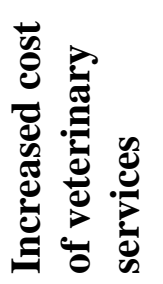 & 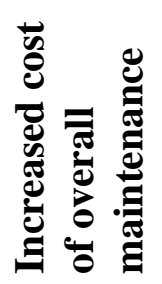 & 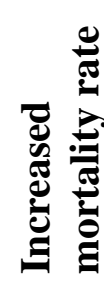 \\
\hline $\begin{array}{l}\text { Most affected by } \\
\text { increased cost of } \\
\text { veterinary services }\end{array}$ & 1 & 4.25 & 3.50 & 3.50 & 3.92 & 4.25 & 4.67 & 4.75 & 4.50 & 3.50 \\
\hline $\begin{array}{l}\text { Most affected by } \\
\text { increased cost of } \\
\text { feeding }\end{array}$ & 2 & 4.29 & 3.03 & 2.79 & 3.68 & 4.84 & 4.26 & 1.58 & 3.74 & 2.97 \\
\hline $\begin{array}{l}\text { Most affected by } \\
\text { increased incidences } \\
\text { of poultry diseases }\end{array}$ & 3 & 4.74 & 4.23 & 4.00 & 3.90 & 3.90 & 4.16 & 1.65 & 2.39 & 2.74 \\
\hline $\begin{array}{l}\text { Highly affected by } \\
\text { increased cost of } \\
\text { feeding }\end{array}$ & 4 & 3.13 & 2.10 & 2.86 & 3.45 & 3.86 & 3.14 & 1.32 & 2.00 & 2.41 \\
\hline
\end{tabular}

\section{DISCUSSION}

Smallholder poultry farmers perceived an increase in temperature and a decline in rainfall intensity in the study area. Chah et al (2013) expressed that increased temperature levels have a critical influence on poultry farming. Reduction in egg quantity, quality and size, and loss of weight affecting meat production were some of the perceived impacts affecting poultry production (Table 1). The implications of climate change on the poultry industry include heat stress, water contamination and recurrent outbreaks of diseases, failing vaccinations, increased rearing mortality, and reduced productivity (Adejoro, 2017). Other validated effects according to the author ranges from production, fixed and operational cost disequilibrium to bio-security, nutritional, health, sustainability and profitability glitches. 
Ravichandran and Mohamed's (2015) account of the evaluation of the impact of increasing temperature on the survival and performance of poultry birds by the Indian Council for Agricultural Research (ICAR) indicated that an ambient temperature of $\geq 34^{\circ} \mathrm{C}$ induced heat stress on poultry birds. The increase in temperature ultimately increased the mortality rate of meat type chickens by $8.4 \%$, layer birds by $0.84 \%$, and indigenous chickens by $0.32 \%$. At an ambient temperature of $37.9^{\circ} \mathrm{C}$, feeding rates of birds decreased significantly to $68.9 \mathrm{~g} / \mathrm{bird} / \mathrm{day}$ against the regular $108.3 \mathrm{~g} / \mathrm{bird} / \mathrm{day}$ at $31.6^{\circ} \mathrm{C}$. There was a further recount of decreased egg production in broiler and layer breeders by $7.5 \%$ and $6.4 \%$ respectively. This empirical evidence indicates the vulnerability of the poultry industry to climate change, particularly to increased temperature levels. The birds' temperature tolerance levels within which they can efficiently reach productivity peak is narrow as higher temperature increases their thermal stress, affecting their appetite and metabolism. As an example, certain enzymes will not function at high thermal ranges, reducing the feeding and digestion capacities of birds (Adesiji et al, 2013; Elijah \& Adedapo, 2006).

According to empirical studies (Elijah \& Adedapo, 2006; Ravichandran \& Mohamed, 2015), higher temperature affects not only the sizes of eggs produced, but also the rate of droppings affecting the quantity of egg production. Other related issues include production of thin or cracked eggshells as a result of inadequate feed intake of birds to stimulate the production of sturdy shells. Its implication ranges from threatening of protein consumption and food security to adversely affecting industrial businesses as eggs are widely used in vast food trades, confectioneries, and in cosmetics and vaccine production. Increasing temperature and decreasing humidity could also give rise to certain bacterial and fungal growths leading to disease outbreaks such as coccidiosis, haemorrhagic syndrome, fowl pox, and bronchitis (Alade \& Ademola, 2013), while increased wind speed could further spread air-borne diseases in poultry birds (Chah et al, 2013; Guèye, 2003). Loss of farm income earnings is thus expected as a direct effect of the aforementioned issues associated with climate change impacts. Alade and Ademola's (2013) study provided evidence of the reduction of the value of poultry products and profitability due to the budding climate change crisis.

Adesiji et al (2013) emphasised the effect of climate change on feed grain production and availability; suggesting that increased temperature and sharp rainfall decline affects the yields, harvesting, and supply of grains. This increases poultry production costs as intensive poultry is heavily reliant on grains. Protracted drought also affects the quality and storage efficacy of raw feed materials as they are contaminated with mycotoxins which are ancillary metabolites of fungi with toxic effects on livestock (Adejoro, 2017). Mengesha (2011) elucidated that climate change has given rise to food-feed competition between the human and animal population, hence, the need to search for alternative feed ingredients for poultry birds. Increased costs of feeding has overtaken increased livestock prices, affecting the profitability of poultry producers (Mengesha, 2011; Schnepf, 2011). In the Eastern Cape Province, for instance, there was an increase in the cost of poultry feed between 2015 and 2016. Broiler starter price increased from R292.80 to R302.20 (3.2\%), Broiler finisher from R281.50 to R290.90 (3.3\%), Broiler post-finisher from R271.10 to R280.50 (3.5\%), Growers mash from R254.60 to R261.00 (2.5\%), and layers mash from R258.10 to R264.70 (2.6\%) (Umtiza Foods Feeds \& Seeds, 2017). Though the price increase may be considered as inconsequential by many, it is critical to be reminded that the majority of the smallholder farmers in this region live below the poverty line (Westaway, 2012) and are barely at a threshold of survival. Thus, 
an increase in the cost of feeding, regardless of its insignificance, still affects the resources of this poor household farming population.

The adaptation responses in the study area were limited to rearing different varieties of birds, destocking, and dependence on social welfare (Table 2). A further analysis of the perceived effectiveness of the adopted responses indicated that none of the measures were perceived by the farmers as significant. This suggests that adaptation to climate change impacts by the poultry farmers is extremely poor. There is therefore an urgent need to set up intervention mechanisms to better assist these local farmers. For instance, it is crucial to create awareness on the relevance of using improved breeds of poultry birds that are more tolerant to climate stresses. Hoffman (2013) pointed out that a genetically diverse livestock population allows farmers to select new breeds developed to respond to threats of changing climate conditions. According to Chah et al (2013), where unimproved breed stocks fail to survive, resistant poultry birds have been found to thrive and complete their life cycles in the face of climatic stresses. Thus, using improved breeds is an expedient adaptation response to climate change.

It is a longstanding knowledge that the majority of the rural population rear more unimproved indigenous poultry birds because they are sturdier, and it requires the birds to self-scavenge with the provision of limited or no supplementary feeding, health care or housing (Kingori, Wachira \& Tuitoek, 2010). This may be a potential reason why more than $50 \%$ of the poultry farmers in the study area took up rearing of different poultry varieties as an adaptation response, bearing in mind that it was still perceived as an ineffective measure. One possible reason could be that indigenous poultry production is still heavily characterised by low productivity and commercial exploitation as compared to the hybrids (Ochieng, Owuor \& Bebe, 2010). According to Gupta (2015), a lack of indigenous breed improvement programmes and other requisite poultry management practices exudes smallholder poultry farmers' inefficiencies. Therefore, it is not clear or certain that these indigenous birds can completely withstand climate change impacts. As a counter measure, breeding programmes to further improve the sturdiness of indigenous birds to climate change should also be encouraged.

Furthermore, constructing buildings with better natural ventilation systems, planting fast growing trees to provide shade for buildings, and installing cooling equipment are adaptation responses aimed at combating high temperature levels. Having earlier established that extreme temperature affects performance levels of poultry birds particularly, their feeding, feed conversion, egg production (quality, quantity and sizes), and the farmers' profitability in the long run, it is critical for poultry farmers to adopt good ventilation practices appropriate for dry conditions in the study area. AEA Energy and Environment (2007) stated the necessity to construct new buildings or adapt naturally ventilated buildings to mechanical ventilation systems for poultry that are still kept under a naturally ventilated environment. Ravichandran and Mohamed (2015) also noted the significance of constructing well aerated new poultry houses, and the installation of cooling equipment to effectively cope with extreme temperature levels. Treatment of birds is another critical adaptation response that should be encouraged amongst rural poultry farmers. Training programmes should be initiated where these farmers can be instructed in disease prevention, management and treatment techniques, particularly in the use of vaccines. Vaccination is especially critical in poultry disease prevention and control (Marangon \& Busani, 2007).

Moreover, engaging farmers in training or capacity development programmes is a major functional responsibility of the agricultural extension institutions. According to Mustapha, 
Undiandeye and Gwary (2012:53), educating farmers must "move beyond technical training to enhance farmers' abilities for planning, problem solving, critical thinking, prioritising, negotiating, building consensus and leadership skills, working with multiple stakeholders, and being proactive". Therefore, extension services should take this into cognisance in their efforts to provide technical trainings and supports for poultry farmers in mitigating climate stresses on production. In the opinion of Maponya and Mpandeli (2013), accessing climate change information through extension services may likely increase the chances of farmers' adoption of specific adaptation techniques and skills. Similarly, the Global Alliance for Climate-Smart Agriculture (GACSA, 2016) affirmed that extension services' role in climate change mitigation should include "technology development, strengthening farmers' capacity, facilitation and brokering, and advocacy and policy support".

\section{CONCLUSION AND RECOMMENDATIONS}

The farmers perceived increase in temperature and decline in rainfall intensity in the study area. Some of the perceived impacts were reduction in quantity of egg production, egg quality and sizes, loss of weight affecting meat production, and mortality rate of birds. Adaptation responses were extremely limited. A further analysis of the perceived effectiveness of the adopted responses indicated that none of the measures were perceived as significant, suggesting poor adaptation to climate change in the study area. There is therefore a need to plan and execute adaptation response schemes to promote effective awareness of and adaptation to extreme climate conditions. Productivity and efficient commercialisation of both indigenous and hybrid poultry productions should be strengthened.

\section{REFERENCES}

AEA ENERGY \& ENVIRONMENT, 2007. Adaptation to climate change in the agricultural sector. Available from: https://ec.europa.eu/agriculture/sites/agriculture/files/externalstudies/2007/adaptationclimate-change/full-text_en.pdf

ADEJORO, S.O., 2017. Poultry industry in Nigeria and climate change implications. Available from: https://en.engormix.com/mycotoxins/articles/poultry-industry-nigeria-climate$\underline{\mathrm{t} 40160 . \mathrm{htm} . \mathrm{S}}$

ADESIJI, G.B., BABA, S.T. \& TYABO, I.S., 2013. Effects of climate change on poultry production in Ondo state, Nigeria. Russ. J. Agric. Socioecon. Sci., 14(2):55-60.

AGNEW, M. \& GOODESS, C., 2009. Common tools and central datasets: Developing a conceptual framework. Available from: https://www.google.co.za/url?sa=t\&rct=j\&q=\&esrc=s\&source=web\&cd=1\&cad=rja\&u act $=8 \& v e d=0$ ahUKEwjtxtvr5u XAhVZOMAKHTGNAhMQFggsMAA\&url=https $\% 3$ A\%2F\%2Fcrudata.uea.ac.uk\%2Fprojects\%2Fcirce\%2Fconcept_framework_2ndDRAF T.doc\&usg=AOvVaw1_-ciJuBAOvwk0E-8tOFxq

ALADE, O.A. \& ADEMOLA, A.O., 2013. Perceived effect of climate variation on poultry production in Oke Ogun area of Oyo State. J. Agric. Sci., 5(10):176-182.

BESBES, B., TIXIER-BOICHARD, M., HOFFMANN, I. \& JAIN, G.L., 2007. Future trends for poultry genetic resources. In Proceedings of the International Conference of Poultry in the 21st Century: Avian Influenza and Beyond, pp.5-7. 
BURNS, R.P, \& BURNS, R., 2008. Business research methods and statistics using SPSS. London: Sage Publications Limited.

CHAH, J.M., ODO, E., ASADU, A.N. \& ENWELU, I.A., 2013. Poultry farmers' adaptation to climate change in Enugu north agricultural zone of Enugu state, Nigeria. J. Agric. Ext., 17(1):100-114.

COSTER, A.S. \& ADEOTI, A.I., 2015. Economic effects of climate change on maize production and farmers' adaptation strategies in Nigeria: A Ricardian approach. J. Agric. Sci., 7(5):67-84.

EITZINGER, J., ORLANDINI, S., STEFANSKI, R. \& NAYLOR, R.E.L., 2010. Climate change and agriculture: Introductory editorial. J. Agric. Sci., 148(5):499-500.

ELIJAH, O.A. \& ADEDAPO, A., 2006. The effect of climate on poultry productivity in Ilorin Kwara state, Nigeria. Int. J. Poult. Sci., 5(11):1061-1068.

FARAUTA, B.K., EGBULE, C.L., IDRISA, Y.L. \& AGU, V.C., 2011. Farmers' perceptions of climate change and adaptation strategies in northern Nigeria: An empirical assessment. Available from: http://www.atpsnet.org/Files/rps15.pdf

GLOBAL ALLIANCE FOR CLIMATE-SMART AGRICULTURE (GACSA), 2016. Compendium climate-smart agriculture \& extension. Available from: http://www.fao.org/3/a-bl361e.pdf

GUÈYE, E.F., 2003. Information dissemination for family poultry research and development. Livestock Res. Rural Dev., 15(2):1-10.

GUPTA, A.K., 2015. Case studies of successful pro-poor value chain models in India. Available from: http://www.ruralfinanceandinvestment.org/sites/default/files/Case $\% 20$ studies $\% 20 \mathrm{of} \% 2$ 0pro-poor\%20value \%20chain\%20model\%20in\%20India\%20_Abhinav_v2-1.pdf

HOFFMANN, I., 2013. Adaptation to climate change - exploring the potential of locally adapted breeds. Animal, 7(2):346-362.

JUANA, J.S., KAHAKA, Z. \& OKURUT, F.N., 2013. Farmers' perceptions and adaptations to climate change in sub-Sahara Africa: A synthesis of empirical studies and implications for public policy in African agriculture. J. Agric. Sci., 5(4):121-135.

KASSIE, B.T., HENGSDIJK, H., RÖTTER, R., KAHILUOTO, H., ASSENG, S. \& VAN ITTERSUM, M., 2013. Adapting to climate variability and change: Experiences from cereal-based farming in the Central Rift and Kobo Valleys, Ethiopia. Environ. Manag., 52(5):1115-1131.

KINGORI, A.M., WACHIRA, A.M. \& TUITOEK, J.K., 2010. Indigenous chicken production in Kenya: A review. Int. J. Poult. Sci., 9(4):309-316.

KITINYA, K.T., ONWONGA, R.N., ONYANGO, C., MBUVI, J.P. \& KIRONCHI, G., 2012. Climate change and variability: Farmers' perception, experience and adaptation strategies in Makueni County, Kenya. Asian J. Agric. Rural Dev., 2:411-421.

KÖBRICH, C., REHMAN, T., \& KHAN, M., 2003. Typification of farming systems for constructing representative farm models: Two illustrations of the application of multivariate analyses in Chile and Pakistan. Agric. Sys., 76(1):141-157. 
LAY, D.C., FULTON, R.M., HESTER, P.Y., KARCHER, D.M., KJAER, J.B., MENCH, J.A., MULLENS, B.A., NEWBERRY, R.C., NICOL, C.J., O'SULLIVAN, N.P. \& PORTER, R.E., 2011. Emerging issues: Social sustainability of egg production. Available from: https://pdfs.semanticscholar.org/1ad5/e1c66e94400ddbac65c93f0ac99ec247d3ac.pdf

MAPONYA, P. \& MPANDELI, S., 2013. The role of extension services in climate change adaptation in Limpopo Province, South Africa. J. Agric. Ext. Rural Dev., 5(7):137-142.

MARANGON, S. \& BUSANI, L., 2007. The use of vaccination in poultry production. Rev. Sci. Tech., 26(1):265.

MENGESHA, M., 2011. Climate change and the preference of rearing poultry for the demands of protein foods. Asian J. Poult. Sci., 5(4):135-143.

MOORHEAD, A., 2009. Climate, agriculture and food security: A strategy for change. Available

from: https://cgspace.cgiar.org/bitstream/handle/10568/33395/StrategyForChange.pdf?sequen ce $=1 \&$ isAllowed $=y$

MUSTAPHA, S.B., UNDIANDEYE, U.C. \& GWARY, M.M., 2012. The role of extension in agricultural adaptation to climate change in the Sahelian Zone of Nigeria. J. Environ. Earth Sci., 2(6):48-58.

OCHIENG, J., OWUOR, G. \& BEBE, B.O., 2010. Pattern of management interventions' adoption and their effect on productivity of indigenous chicken in Kenya. Paper presented to The China Agricultural Economic Review and International Food Policy Research Institute (CAER-IFPRI) Conference on Agriculture and the Wealth of Nations. Beijing, China.

OKONYA, J.S., SYNDIKUS, K. \& KROSCHEL, J., 2013. Farmers' perception of and coping strategies to climate change: Evidence from six agro-ecological zones of Uganda. $J$. Agric. Sci., 5(8):252-263.

PERMIN, A., PEDERSEN, G. \& RIISE, J.C., 2001. Poultry as a tool for poverty alleviation: Opportunities and problems related to poultry production at village level. In Australian Centre for International Agricultural Research Proceedings, pp.143-147.

PETTENGELL, C., 2010. Climate change adaptation: Enabling people living in poverty to adapt. Available from: docserver.ingentaconnect.com/deliver/connect/oxpp/20530234/v6n2/s1.pdf?expires $=15$

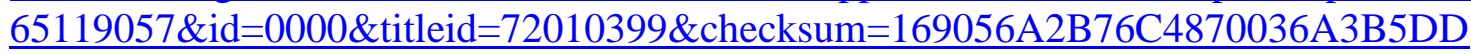
0C469B9

RAVICHANDRAN, M.P. \& MOHAMED, A.K., 2015. A study of the perceived effects of climate changes on commercial layer egg industry with respect to total production, egg price behavior, and diseases among layer poultry farmers at Namakkal District, Tamilnadu, India. Available from: www.akamaiuniversity.us/PJST16_1_345.pdf

SCHNEPF, R., 2011. U.S. Livestock and poultry feed use and availability: Background and emerging issues. Available from: http://farmpolicy.com/wpcontent/uploads/2011/09/CRS_LivestockPoultryFeedUse11Aug.pdf

SEBHO, H.K., 2016. Exotic chicken status, production performance and constraints in Ethiopia: A review. Asian J. Poult. Sci., 10:30-39. 
S. Afr. J. Agric. Ext.

Vol. 47 No. 3, 2019: 108 - 119

http://dx.doi.org/10.17159/2413-3221/2019/v47n3a519
Popoola, Monde \& Yusuf

(License: CC BY 4.0)

UMTIZA FOODS FEEDS \& SEEDS., 2017. 270 High St. Alice, Eastern Cape Province, South Africa.

WESTAWAY, A., 2012. Rural poverty in the Eastern Cape Province: Legacy of apartheid or consequence of contemporary segregationism? Dev. South. Afr., 29(1):115-125. 
